NOTE: This is a self-archived post-print of Lara Putnam, "Sentiment and the Restrictionist State: Evidence from the British Caribbean Experience, circa 1925," Journal of American Ethnic History 35, no. 2 (Winter 2016): 5-31.

\title{
Sentiment and the Restrictionist State: Evidence from the British Caribbean Experience, ca. 1925
}

By Lara Putnam

The international mobility control regime consolidated in the decade after World War I made intimate sentiment a systematic concern for states policing borders and rights. New U.S. immigration laws in the 1920s made family reunification one of the few routes through which migrants could enter the United States when their home society's quota was exhausted. (That is, the laws extended to much of the world both the exclusionary stance and the kin-based exceptions pioneered in regard to Asian migrants a generation before. ${ }^{1}$ ) Adjudicating the right to cross borders and work now required state agents to assess intimate bonds and the intentions they fostered: the sentimental as well as documentary dimensions of kinship. The impact of this shift was felt sharply in the British Caribbean, which was placed under quota restriction for the first time in 1924, cutting legal immigration from the islands from over ten thousand to under five hundred per year.

For migrants and would-be migrants, family acquired a contradictory relationship to state power. On the one hand, family ties became more important than ever in supporting mobility, providing not only resources and support (as had long been the case) but also--for a select few-formal entitlement to entry. On the other hand, kin practice became a key point of vulnerability for working-class migrants, as the U.S. government placed itself in the position of verifying the highly restricted set of family ties that could justify non-quota entry under the new law. Commonplace Caribbean practices like consensual unions, sibling reliance, and informal fostering created bonds given no protection under U.S. immigration law. Moreover, the new state interest created a new venue for intrafamily dispute. Raising the stakes of family ties, the restrictionist regime offered tempting leverage to those struggling with straying spouses, headstrong offspring, or scofflaw siblings. Men and women alike could and did seek to use this leverage, but it was a blunt instrument, unpredictable and often irreversible. Its power to harm was far more consistent than any power to help.

The importance of family to immigration restrictionism has been studied by scholars along three separate axes. Firstly, scholars have noted that fears surrounding sexual coupling drove the eugenicist case for restriction, centered on the supposed heritability of "feeblemindedness" and "criminality," the demographic consequences of differential fertility, and the "social traits of the hybrid" who resulted from "race crossing." Secondly, scholars have called attention to the ways the immigration apparatus measured would-be migrants against middle-class, patriarchal, heterosexual norms and barred or expelled those found lacking. ${ }^{3}$ Thirdly, scholars have analyzed the role of family reunification policy in shaping both opportunities for inclusion and patterns of exclusion. ${ }^{4}$

A different dimension of state enmeshment with intimate life--related to all of the preceding, but distinct from them--comes to the fore in documents generated by entry officials and consuls abroad as the 1924 Johnson-Reed Act came into operation. Written into the new regulatory instruments were myriad matters for which border-crossers' sentiments, and not 
merely their bodies, morals, documents, or acts, needed to be assessed. Had a permanent resident left the United States with the intention of return, or to follow her heart elsewhere? Which kinds of family ties made an islander's quick return to the islands a sure bet, justifying "bona fide nonimmigrant" status? Which lures might induce a sojourner instead to stay? While family reunification rules remitted to the formalities of kinship--birth and marriage certificates above all--these ancillary questions turned state agents' eyes to kinship's informal dimensions instead. In doing so, the process offered wide scope for perceptions of race, class, and virtue to shape the extension of rights.

This essay uses micro-historical sources to evaluate the consequences of the sentimental interests of the restrictionist state. Because micro-level sources allow us to get at the actual functioning of law, it is through them that we can learn how it came to be that laws that were formally race-blind, class-neutral, and silent on gender brought results that were race- and classbiased and created new burdens for women in particular. Judging merely by the letter of the law, the United States was the exception to an era of anti-black xenophobia, which saw immigrants of "Negro race" explicitly banned in Panama, Costa Rica, the Dominican Republic, Venezuela, and beyond in the 1920s and 1930s. But when we look at results evidenced in entry statistics, we see that U.S. law was applied to function as a de facto ban on black entry. ${ }^{5}$ Not so race-blind after all, and not so exceptional.

And when we shift our gaze to the micro-level processes that generated those results, we see that the new laws used family to police borders in ways that were anything but genderneutral. With determination of sentimental intent now essential, state agents looked to testimony from family and friends to judge where sentiment lay. Ideas about proper female behavior, maternal feeling, and sexual virtue had a major impact on how cases were adjudicated: the ideas of state agents first and foremost, but the ideas of community and family members as well. That did not mean women were always kept out and men always let in: quite the contrary. But it meant gendered constructs shaped the gates to legal mobility.

It is also micro-level sources that show us that in practice, family testimony could work against claimants but rarely in their favor. At least for the migrants studied here--all literate, working-class, English-speaking, and "Negro"--state agents listened carefully for testimony that undercut claims to entry, and discounted testimony that supported those claims. In a sense, this was the functional counterpart, albeit spatial opposite, of the "remote control" policing via consulates abroad that Ari Zolberg identified. ${ }^{6}$ The power to force territorial exclusion--but not the ability to countermand it--was placed in the heart of the family.

To what extent were these dynamics particular to Caribbean immigrants, and to what extent shared by other non-white, or non-Anglo-Saxon, or even all non-citizen claimants? These are questions for future research. Aspiring immigrants of many origins came under restrictive quotas by 1924. The U.S. consul in Havana, when asked in December 1924 how many "aliens now in your consular district ... would proceed immediately to the United States if the quota restrictions were removed," offered a glimpse of the global chains interrupted by the new U.S. law. Six thousand Russian and Polish Jews, he reported, three thousand Spaniards, two thousand "Jamaican Negroes," and smaller numbers of others. ${ }^{7}$ This glimpse of Havana jammed with desperate and polyglot would-be entrants suggests the potential reach of the processes explored below. From Brooklyn to Barbados and far beyond, the immigration regimes cemented in the interwar years both radically disrupted family practice and radically shifted the role of family in the allocation of rights to non-citizens. 


\section{Setting the Stage: Caribbean Families and New York Streets}

Ada C. and Samuel A. met in Panama, 1,500 miles away from the isle of Barbados where both had been born. They were married in the Canal Zone's Episcopal church in 1913. Things did not go well. Within a few years, Ada had returned to Barbados and, from there, ended up in Havana, perhaps after several years spent working in the United States (her sister Theresa was in Philadelphia and her cousin Mae, in Harlem). ${ }^{8}$ For his part, Samuel left Panama in 1920, after fourteen years laboring there, to seek work in Cuba along with thousands of others like him. Over 27,000 British Caribbeans entered Cuba that year, thousands of them declaring a last place of residence other than their country of birth. ${ }^{9}$ Samuel did not stay long. In August 1920, he took a boat from Havana for Key West, giving as his destination the home of his twenty-six-year-old cousin Beatrice Reed in Brooklyn, where she headed a household that included two other women and nine men, all in their twenties and thirties, all classed as black and all native English speakers: one born in Cuba, two in North Carolina, two in the "West Indies," five in Puerto Rico. ${ }^{10}$

Ada and Samuel had not always stayed in touch, and Ada would later say she "did not know when" Samuel left Panama for Cuba or Cuba for the United States. But somehow, in Havana, they had reconnected. A month after Samuel's departure for Key West, Ada shipped out of Havana on a boat bound for New York, her husband and his new Brooklyn address her destination. $^{11}$

The world she stepped into was one of rhythmic brownstone and cacophonous humanity: all-white blocks filled with Irish, Italian, Russian, and Swedish immigrants and their growing New York-born families; all-black buildings full of Barbadians, North Carolinians, Virginians, and more Barbadians: the men working as porters, elevator operators, and factory laborers, the women as housemaids in private homes. ${ }^{12}$ Samuel worked at the YMCA and Ada at St. Christopher's Hospital. Soon they moved six blocks north to Cumberland Street, where landlady Edna James (herself the New York-born child of a British Caribbean father and a mother from Virginia) rented one floor of her fourteen-room house to tenants, who in 1920 included her husband's brother-in-law and cousin, the cousin's wife, a Dutch Caribbean seaman and his Alabama-born wife, and another British Caribbean couple. ${ }^{13}$

\section{< FIGURE 1 ABOUT HERE $>$}

What were they doing in Gotham, so many islanders far from home? The answer points to a multi-generational process through which labor migration and Caribbean life became inextricably linked. In the era after emancipation (1834-1838), the descendants of freedpeople faced a grim panorama. Plantation elites refused to pay the wages that would have drawn free workers into steady employ, instead using their political clout to demand subsidized indentured immigration from India, re-creating the unfree workforce they preferred. In response, Afro-West Indians sought opportunity overseas but nearby, forming migratory circuits in the eastern Caribbean (with movement from Barbados, Grenada, St. Vincent, and other Windwards southward to Trinidad, Guiana, and Venezuela) and the western Caribbean (as Jamaicans traveled to Colón, Bocas del Toro, Port Limon, Bluefields, and other littoral settlements). The few Caribbeans whose families could afford multi-year schooling found island careers blocked by unspoken rules preferring white Europeans to locals of color; increasingly, British Caribbeans of this class sought opportunity in the United States as ministers, publishers, doctors, and teachers. $^{14}$

The expansion of U.S. investment at the start of the twentieth century drew on and accelerated these pre-existing circuits. Labor recruiting for Panama Canal construction after 1904 
for the first time drew large numbers of eastern Caribbean migrants to the western rimlands, while intensified investment in sugar transformed the northern Antillean islands of Cuba and Santo Domingo into major destinations as well. As increased shipping brought down ticket prices, the relative ease of movement meant folks rarely moved only once. Families bootstrapped their way to collective advance as news, children, and earnings crisscrossed the region. ${ }^{15}$

While the initial migrant flow to any given destination was usually seventy-five to eighty percent male, at each, the portion of women among arrivals grew over time, as island women found a market for their skills in the booming ports their brothers and cousins helped build. Women ran boarding houses, laundered clothes, made pastries for sale. Cities offered women both high demand for their labor and supportive neighbors to cushion the risks that mobility (and men) brought, and by 1920, New York City had become the most important destination for women from across the Anglophone Caribbean. ${ }^{16}$ Women made up fifty percent of the 35,000 black immigrants who entered the United States from 1918 to 1922 and fifty-five percent of the twenty thousand who did so from 1923 to $1924 .{ }^{17}$ Indeed, by the time the Johnson-Reed Act brought entry to a halt, New York City had the largest population of British Caribbean women and girls on the planet: about forty thousand of them, including locally born daughters, topping Kingston's 37,000 and Port of Spain's 34,000 women and girls. ${ }^{18}$ In total, by 1930, 42,000 foreign-born West Indians resided in Manhattan, thirteen thousand in Brooklyn, and six thousand elsewhere in New York City--along with 57,000 of their locally born children. ${ }^{19}$

Writing in 1943, pioneering journalist Roi Ottley marveled at the "bewildering array of clans, tribes, races, cultures, and colors" on Harlem's streets. ${ }^{20}$ Yet the explosion of diversity reflected a prosaic pattern: social networks made migration happen. What could look like exotic fragmentation in fact indexed enduring connection, both among those arriving and between them and distant homes. Indeed, Ottley himself grew up in a household on West 136th Street in the 1920s that exemplified this reality. His parents had reached Harlem from Grenada in 1904, part of the early, small wave of arrivals from the British islands' middle classes of color. Circa 1900, these were the only Afro-Caribbeans with the resources to pay passage north out of pocket. The migrants who turned the United States-bound stream into a flood in the years after the Great War, in contrast, were more heavily drawn from the working classes, leveraging resources marshaled by kin from sojourns in the circum-Caribbean.

We see this in the trajectories of the thirteen lodgers, from Grenada, St. Vincent, Jamaica, and beyond, to whom Roi Ottley's mother and father, in 1920, sublet rooms. ${ }^{21}$ Consider lodgers Vinette Hunter and Miriam Vaz, born in Jamaica in 1900 and 1898 respectively, who had entered the United States in 1917 and 1918 and now both worked as seamstresses in a dress factory. A working woman who relied on family earnings from the Spanish American republics to make it to Harlem, Vinette was typical of early 1920s arrivals, and her trajectory tells us much about the transnational ties of working-class Caribbeans in this era. Vinette sailed to New York from Panama in 1918, the "show money" she carried provided by her mother, who stayed behind in Colón. The big city awaiting was hardly anonymous: Vinette would join her Aunt Claire, a schoolteacher who had reached New York from Kingston in 1916 alongside her brother and his wife. ${ }^{22}$ By 1930--ten years after we met her in Roi Ottley's household--Vinette had married George Vaz, a British Caribbean born in Panama in 1897 to Panama-born parents (and perhaps a relation of her 1920 roommate, Miriam Vaz). George had come to the United States in 1914 and now worked as a bellman in a hotel; his younger brother Clifford, who had moved to the United States at age nine, two years after George, now worked as a merchant seaman. Meanwhile, Vinette's mother had joined Vinette in New York in 1921, and, in 1930, resided with Vinette and 
George, doubtless minding three-year-old George, Jr., since Vinette still worked as a dressmaker in a factory. Eight lodgers hailing from Texas to Georgia to Long Island rounded out the household. $^{23}$

Gazing up and down the street from the Vazes' Edgecombe Avenue stoop in 1930, we see that the Vazes' connections to the Spanish-speaking circum-Caribbean were not exceptional. The house next door was headed by Virginia-born William Ward and his Panama-born wife, Marie. Like George and Clifford Vaz, Marie was a native speaker of English whose parents were both of Panamanian birth. William and Marie had surely met in Panama, where their eldest daughter Cleopatra was born in 1916; they had relocated to New York in 1923. One of the Wards' eight lodgers was from the British Caribbean, the others from Virginia, West Virginia, North Carolina. On the Vazes' other side was a less international household: only one of the lodgers had been born abroad, in the Virgin Islands, although another was New York-born to British Guianese parents. Next door, a sixty-four-year-old widow from North Carolina rented rooms to six lodgers, including a couple from Bermuda, a man from South Carolina, a man born in Panama to British Caribbean parents, and British Honduran Thomas Martinez and his twoyear-old New York-born son. All were Negro, according to census takers, just like every resident of this long block. ${ }^{24}$

People like Vinette, George, and Marie would have identified as British West Indian, although their degree of connection to the British colonies varied widely. More than simply islanders--indeed, sometimes not island-born at all--they were products of the circum-Caribbean migratory sphere, and this had patterned their life experiences in common ways. Their parents or grandparents had left their home islands to seek opportunity abroad, and they themselves had spent their youth on polyglot streets of tropical ports, finding commonality and difference with Spanish-speaking mestizo laborers, Chinese shopkeepers, Yankee bosses, and islanders from across the Caribbean. Each had negotiated the bureaucracies of at least three different political systems--the British colonies that issued his or her passport, the Spanish American republic where he or she had resided, and the United States to which he or she had gained entry--in many cases, before turning twenty.

The historiography of labor migration in the early twentieth-century Caribbean, disproportionately focused on male workers and employers like the United Fruit Company, has not wondered enough about the kinship structures undergirding this mobility. ${ }^{25}$ As we have seen, most initial migrant flows were heavily male, but in receiving-society ports, British Caribbean populations were balanced or female-predominant, and New York-bound migration was the extreme version of this trend. Women outnumbered men among Caribbeans entering the United States from 1918 onward, and they headed to New York above all. Over seventy percent of them were single. ${ }^{26}$ They worked as housemaids, dressmakers, cleaning staff; they were of what demographers call prime reproductive age. Was no one having sex? Was no one getting pregnant? And if they were, given that almost all these women worked all day--or all week-outside the home, who was minding the children? The answers are consistent with what we know about international migration and reproductive labor from the contemporary world. Family did the work of family--but family as understood by participants, which meant a much wider web than mother, father, and child.

Across the British Caribbean, post-emancipation women's roles encompassed ownaccount farming and marketing as well as daily reproductive labor in their own homes. Customary forms like "family land" emerged to spread among expansively reckoned kin the security that land access offered. Neither formal marriage nor nuclear family was a key building 
block of communal life for the majority of Caribbean people. Legal marriage was class-specific in its timing: for women of the region's elite and middle classes, marriage preceded sexual union, but for the rural and working-class majority, church marriage came as the culmination of a long reproductive life. For most women, that life included one or more early, non-residential partnerships as well as later enduring co-residential unions. As a result of these combined trends, across the nineteenth and twentieth centuries, roughly two-thirds of Caribbean children were born to unmarried mothers. Their siblings, half-siblings, aunts, uncles, and grandmothers were critical sources of support. $^{27}$

These kin forms proved extraordinarily well adapted to an era of intense long-distance labor mobility--indeed, they may have become entrenched in Caribbean family practice for precisely that reason. ${ }^{28}$ The correspondence of U.S. consuls in Caribbean ports in the 1920s reveals a world of children and siblings in motion, as parents relied on kin back home to raise their children while they worked "in foreign." Vinette Vaz's mother traveled from Panama to Harlem to reside with her daughter and grandson, but, more commonly, children went to gran rather than gran to children. Indeed it was a recognized pattern at the time for British Caribbean women who became pregnant in New York to go home to the islands to give birth and return within the year, leaving the child behind in the care of female kin. ${ }^{29}$

Temporary child-shifting and serial reunion seem to have been nearly universal among British Caribbeans seeking advance in the North, whatever their class. Unitarian minister and Harlem civic leader Reverend Ethelred Brown wrote to the U.S. consul in Kingston in 1923 seeking visas for his "last two children," aged sixteen and eleven, "on the ground of coming over to join their parents who are able to take care of them." ${ }^{30}$ Census returns show that the Browns' eldest son had preceded his parents to the United States in 1919, at age eighteen; one daughter had arrived a year after the couple, when she was eighteen; and the oldest and youngest daughters, then ages twenty-two and eight, followed the year after that. By 1924, the parents and six children lived reunited on St. Nicholas Avenue. ${ }^{31}$ Arthur Barker waited until his son was sixteen before sending for the boy and his grandmother, who had been raising him, to join Arthur and his wife in New York. Arthur was a mail clerk and homeowner, a U.S. resident since 1907 and naturalized citizen since 1914--yet his mother was illiterate, confirming significant intergenerational mobility. There was no impediment to Arthur's mother's migration, the U.S. consul reassured. ${ }^{32}$ (A year later, as we will see, the answer would be quite different.)

To make the most of the uneven opportunities the circum-Caribbean economy offered, families needed to be able to regroup and rejoin. Barbados-born Donald B. reached New York harbor in 1920 as a seaman, but chose--illegally, as it happens--to stay ashore. In 1922, he married Helen, a Barbadian woman he had met on arrival. Donald already had three children back in Barbados by his deceased first wife. Helen gave birth to his fourth, her first, in New York, but when eight months later, she was expecting her second, she and Donald returned to Barbados with their infant son. Months later, a former employer wrote from the Upper West Side to tell Donald he had work for him, and Donald re-embarked to stay with his brother in New York while Helen stayed in Barbados with the two little ones and their three older (half-) siblings. ${ }^{33}$ Donald could not read or write more than his name, and the doctors at Ellis Island discovered heart disease they thought would be incapacitating: he was barred from entry. But he had done all right for himself and his family so far, in good part because the two-way valve of New York's port had allowed Donald and Helen to redistribute wage earners and dependents across households in multiple countries, making the most of the non-economic resources they could muster. 


\section{Regime Change, 1921-1924: The Imposition of Quotas and the Elevation of Conjugal Ties}

After June 1924, this would no longer be possible. From the point of view of European immigrants, 1924's Johnson-Reed Act intensified a process that had begun with the Emergency Quota Act of 1921, setting numerical caps by "national origins" that both lowered immigration overall, and drastically reduced the numbers of Southern and Eastern Europeans allowed entry. For British Caribbeans, the impact was even more momentous. Johnson-Reed placed the "nonself-governing" colonies of the Americas (e.g., the British West Indies but not British Canada) under quota control for the first time. Covered by the British quota that Johnson-Reed had expanded, British Caribbeans might have continued to travel north in strong numbers. But the State Department ensured otherwise, sending just three hundred of the 34,000 annual British quota numbers to be divided among all U.S. consulates in the British Caribbean. In practice, then, legal entry to the United States by British West Indians without claim to non-quota status had been brought to a halt. ${ }^{34}$

Overnight, "remote control" policing via U.S. consuls became a decisive factor in Caribbean family trajectories. Before 1924, the key issue that U.S. gatekeepers in the circumCaribbean were asked to judge was whether intending emigrants had someone in the United States to rely on for support. Consuls clearly felt comfortable with the presumption that brothers, sisters, and cousins would be there for each other (as indeed they most always were). When Simeon Beckford of Brooklyn wrote to the U.S. consul in Kingston in 1923 to inquire about his sister Theresa Davies--

Please send ' $U$ ' tell me what is the Enderance [illeg.] is it that she cannot get out of the country. I guest she must have not pay to you $\$ 10$ ten dollars for the signing of the PassPort. Sir so doing Please Send and let know. So that I may Send the Money my self and Pay for the Passport are Stamp. So that she may be able to gut through for the Spring.

--the consul immediately reached out to Simeon's sister on the basis of this and an affidavit of support, with no need to question, much less document, their relationship. By April 6, Theresa's passport had been visaed and, the consul wrote to assure Simeon, she was free to travel any time. ${ }^{35}$ Did Simeon and Theresa share two parents? Had their parents been legally married? Stayed together? Did Simeon have other sisters? Was Theresa his favorite? His only favorite? We don't know, of course, because the consul did not need to know and would not have imagined asking.

This presumption that the bonds on which visa applications hinged were strong and reliable, whatever their particulars, with state sanction or without, would two years later look like a quaint vestige of a bygone era. Under the new system, documentation of formal marriage was essential for those seeking family reunification, evidence of ongoing U.S. domicile was essential to claim returning resident status, and proof of permanent foreign domicile and the absence of economic need were essential for a non-immigrant (tourist) visa: and in each case, the details of family sentiment became matters of explicit state interest.

The fact that legal marriage was rare and class-specific within British Caribbean societies now carried portentous consequences. For the channels along which entry outside the quota queue would be permitted as "family reunification" were very narrow. Only legitimate spouses and legitimate minor children of U.S. citizens, and minor children of U.S. citizen mothers regardless of legitimacy, could claim non-quota status. ${ }^{36}$ 
Given that less than a quarter of Caribbean-born residents of the United States were naturalized as of 1930, for the great majority of long-distance parents, the answer was no before the question was even asked. ${ }^{37}$ Mrs. Amy Cozier of Stamford, Connecticut, filed an affidavit of support in April 1924 to bring her son from Bridgetown. Under the law in force at the time, he could have joined her without question. By the time the U.S. consul processed the papers, however, unless Mrs. Cozier had acquired U.S. citizenship, the eleven-year-old was staying right where he was. ${ }^{38}$

Meanwhile, beyond the narrow realm of legal spouses and minor children, even citizens' kin ties opened no doors. An Anglican priest in Antigua wrote on behalf of his servant, "a black, woman, Felicia Charles, Married, but separated from her husband; aged 52 years, who is anxious to go to the USA to join and live with her daughter." Felicia Charles was an excellent cook, the priest assured, and "a woman who is sure to make good." 39 The testimonial was irrelevant. Even if her daughter became a naturalized citizen, Felicia could gain nothing more than preference status on a waiting list for a quota number that would never come. Anna Matthews, a respectable housekeeper "now and for many years past" employed in a Turtle Bay home, sought to bring her brother Joseph's one son and three daughters, ages six to nineteen, from St. Kitts to live with her, documenting her ability to pay for their schooling and support. ${ }^{40}$ Like Amy Cozier and Felicia Charles, Anna Matthews sought a redoubtable (and, frankly, undoubtedly white) interlocutor for her first sally against state power, in her case, the vice president of the Long Island Railroad. Again: no matter what, ten months too late.

Nominally supportive of family reunification, in practice, the system imposed in 1924 cut a fierce breach through precisely the practices of shared childrearing and serial reunion that had made the mass expansion of British Caribbean migration possible in the first place. Even the consuls charged with applying the new rules struggled to wrap their minds around them. What of the hundreds of British Caribbean women, legally resident in New York, who returned to the islands to give birth? The women themselves would maintain non-quota status, as long as they could persuade consuls their "intent" had always been to return, and their Harlem households had remained their "bona fide domicile." But their newborns were non-citizen children of noncitizen mothers. The Kingston consul queried superiors in alarm. "I see nothing in the regulations and instructions whereby they would not come under the quota. If this is the case, a great many of the quota numbers will be used as this office is considering the status of some fifteen or twenty Jamaicans at this time under such circumstances." ${ }^{41}$ By the time Johnson-Reed's new system was understood by those tasked with implementing it, waiting lists for quota numbers were five to twenty times longer than the annual supply at each of the region's consulates. ${ }^{42}$

\section{Sentiment as State Business: The Interrogation of Ada A.}

The state engagement with intimate life occasioned by the restrictionist era went far beyond family reunification constraints. Legal domicile had become key to determining what visa status or right of return a migrant might claim, and bona fide domicile was defined by intent. Agents were asked to judge travellers' hearts, an even harder business than reviewing documentation of birth, marriage, and conduct. New regulations explicitly instructed consuls to presume the possibility of deceit, and not only redouble interrogation but "take any other actions which seems necessary or desirable, in order to ascertain the true facts." 43 Intent's place in the equation was explicit, for instance in guidance to consuls on claims to ongoing U.S. residence. The burden of proof was on the "returning alien" to show "(b) That he went abroad with the intention of returning to reside in the United States," "(c) That he has an established domicile in 
the United States," and “(d) That his stay abroad, if protracted, was caused by justifiable reasons over which he had little or no control." perception rather than deed or document.

The mandate to assess intent almost ensured that government agents' presumptions about gender, sex, race, class, and virtue would shape the rulings that determined migrants' rights. To see how, let us return to Ada and Samuel A., whose travels from Barbados to Panama to Cuba to Brooklyn we traced at the start of this essay.

In fall 1922, Ada heard that her mother "had some trouble" back home. She left Cumberland Street for Barbados, where she lived with her sister and sister's husband while caring for her mother. She had "expected to stay only a few months" but then was "taken sick with fever" herself. ${ }^{45}$ By the time she recovered, it was halfway through 1924 and, she later explained, "I could not get a quota then." Finally, in March 1925, she convinced the U.S. consul in Bridgetown to give her a non-quota visa as a returning resident. On the ship's passenger manifest, prepared for immigration officials in New York, Ada declared that she was travelling to rejoin her husband, who had paid her passage, and that she planned to stay permanently; she showed $\$ 50$ in her possession and reported that she had lived in the United States from 1917 to 1922. The receiving officer scrawled "non quota" across her entry. ${ }^{46}$ So far, so good. However: "Practically every case of an alien returning from abroad from a protracted visit is made the subject of an investigation by the board of special inquiry at the port of entry and many are referred on appeal to the Secretary of Labor," State Department instructions informed the consuls responsible for remote control, and so it was in this case. ${ }^{47}$

After walking Ada through her account of her travels, officials started down a line of questioning that made it clear that a competing tale lay in wait. They asked about a particular man who had traveled on same boat as she to Barbados in 1922. Hadn't he deserted his wife when he left New York? Didn't he talk with Ada on the boat? The crescendo of innuendo was capped with the revelation of an affidavit filed by Ada's husband Samuel in New York two months after Ada's 1922 departure, an affidavit that declared, in officials' words, "that since your arrival in the US you have not been conducting yourself in the proper manner, that you were associating with companions of poor reputation, that on Oct. 111922 you left home and sailed to Barbados taking with you what money the two of you had saved and that you were accompanied by a man named Aubrey Sinclair S. who had abandoned his wife in NY City and had run away with you."

Ada denied all. Samuel must have filed the affidavit because he wanted to marry another woman, she insisted. At first, she had not believed the rumors that had reached her in Barbados that Samuel had taken another wife in her absence, she said, but a woman on the boat with her from Barbados just now had said "she witnessed the wedding" herself. This new plot twist developing, inspectors sent Ada out and summoned Samuel in. They asked him about his and Ada's marriage in Panama, his travels, Ada's arrival from Cuba, his employment history. Had the two any children? "No, but she had one since she went away"--eleven months after her departure, he added pointedly, somewhere in Trinidad where she had stayed with Aubrey S.'s mother. Where was S. now? "Still in Barbados begging his wife [in New York] to send for him." "Q. Have you ever had immoral relations with another woman besides your wife? A. Not while we lived together. Q. Since she went away did you have another woman? A. No." This was a remarkable response, given that by his own account, he had in fact married another woman-then-eighteen-year-old Myrtle C.--a year and three months after Ada left. 
More fundamentally, let us pause to notice and marvel, if we can manage to denaturalize our knowledge of what states do around their borders today, at the interrogation underway. After all, neither Samuel's marital status nor his residence status was at stake in this inquiry (and indeed, neither would be impacted by it: five years later, he and Myrtle and their four-and-a-halfyear-old daughter resided on Atlantic Avenue, a block away from the lodging rooms he and Ada had shared). ${ }^{48}$ The fact that Samuel had "committed bigamy" was noted by interrogators only in passing. Samuel's truculent reply distilled all resentment against Ada: "She was called Mistress S. in Trinidad." And if she were? Why did what she was called in Trinidad matter? Ada was not claiming non-quota status by virtue of her marriage to Samuel: she could not, for he was not a citizen. Theoretically, neither Samuel's morals nor Ada's were under examination. And yet, everything about their conjugal life was--and by law. The burden of proof fell to Ada to demonstrate that she had had "the intention of returning to reside in the United States" when she left; that she had "an established domicile in the United States"; and that her "stay abroad, if protracted, was caused by justifiable reasons over which [she] had little or no control."49 This was about intentions and expectations and loyalties. It was about where home was.

Officials were asked to read backward from subjects' actions to their sentiments, and pass judgment on the sentiments themselves. So their questions burrowed in to intimate choices, and received radically different answers from these two former lovers. Ada had left her husband to stay with a sick mother (or had run away with another man), had visited an uncle in Trinidad (or had stayed with a new mother-in-law there), had lost a child to early death when she herself was a teen in Barbados (or had left a newborn in Trinidad just now to try her luck back in the United States). Samuel had sent letters and sometimes money to Ada in Barbados (or nothing at all); had been humiliated by her affairs and had reproached her for infidelity (or lived in harmony while hatching schemes to wed another). Each one of these allegations appeared in response to specific questions from review board members. This is what officials thought they had to know in order to decide whether Ada A. had a right to walk out onto the streets of New York. The hearing, like so many of its kind, hinged ultimately on the experience of family. For whose needs was the intending immigrant responsible? Who would take them in? Who must want to be with whom?

In light of our preceding discussion of U.S. immigration law's hypervalidation of the conjugal unit and disinterest in kin bonds that had greater Caribbean importance, it is worth noting just how intensely the officials focused on conjugal comity and sexual fidelity. To Ada, they asked, "Did you know that [your husband] did not want you to come here, before you left Barbados?" "Did you have any idea that your husband was interested in another woman when you went away?" "Have you ever been intimate with any other man than your husband?" (She answered no in every case.) All the more so in questions to Samuel. Had Samuel complained to Ada about her conduct? "Do you know if she committed adultery?" Had Samuel had sufficient proof for divorce? Nor was it all about sex. What was the name of the Reverend who had married Samuel and Myrtle? Did they have any children? Had Ada come from Cuba alone in 1920, the inspectors inquired, even though nothing that either Samuel or Ada had said so far implied otherwise? "Alone so far as I know," Samuel responded, letting the new doubt linger. Had Ada had a child with her then? "Not that I know of." Doubt spread.

Apparently disjointed, Ada's concluding statement held up a mirror to the topography of legal concern, reflecting back exactly the issues that state agents had demonstrated, through their questioning, to be relevant. Her words made patent just how central intimate intention, conjugal practice, and reproduction had become to the adjudication of mobility rights under the new regime. Ada's concluding statement, in its entirety: 
I sailed in October 1922 and my husband took me to the dock, pier 24, Brooklyn, S/S Diana and when I got there, he presented me with a watch and he gave me $\$ 7$. He knew this man S. went on the boat the time I did and he knew he was going away to visit his home and I to visit my home, but he wanted to be married again and that is the reason he said I went away with this man. He claims I had a baby but I did not have a baby because this Dr Wilson attended me for woman trouble and he said I could never have babies.

It was on facts such as these that her claim to domicile within the United States now hinged, on sentimental rather than documentary traces of kinship. Had her husband seen her off at the dock with gifts, expecting to welcome her home once her visit to her ailing mother concluded? Had she always intended to return to her home in Brooklyn, or only done so after a Port of Spain dalliance came to nought? Why had she no children to her name?

Such concerns not only preoccupied the Department of Labor inspectors on the review board at Ellis Island; under the remote control system of immigrant screening, interrogation of the domestic details and family lives of visa applicants occupied ever more of consular officials' time. (Again, this has become so routinely the case in all non-rich nations from which working folk seek to depart, that it is hard to remind ourselves just how unnatural such a system seemed at its start.) The transcript of Ada A.'s interrogation appears in Bridgetown consular records because it was forwarded to the consul, as were all transcripts of cases in which officials at Ellis Island reversed the consul's conclusion regarding the "admissibility" of "the alien." The returned transcripts were prefaced by an exhortation to "study the records of the hearings carefully with a view to correcting any errors in your visa practice which may be disclosed by them," with the ominous warning that supervisors in Washington proposed "to scan future performances carefully and to make appropriate notations" on the consul's "efficiency records ... if similar mistakes occur. ${ }^{" 50}$ Consuls who cared about their careers had best emulate the skeptical intimate inquiry that now guarded the golden door.

\section{State Power and Internal Policing}

The restrictionist regime asked officials to attend to the affections of a potentially huge number of people: to wit, all non-citizens seeking to cross U.S. borders. In practice, though, the trigger for investigation and intervention came more often from below than above. When agents of the state ended up in some family's business, it was usually because some family member had wanted them there. Working-class Caribbeans had long used letters and lawsuits, addressed to British officials on the islands or receiving society officials in the rimlands, to seek allies in their intimate conflicts. ${ }^{51}$ As visa requirements created a new point of mandatory state contact, U.S. immigration officials became another looked-to lever.

This was true even before 1924. Mrs. Edward T. wrote to Bridgetown from Ozone Park, New Jersey, in 1923:

To American Consul--

Dear Sir--

If a party named Maud L. or [alternate spelling] should apply to you for a passport she is not entitled to one. My husband (a man unwilling to properly look after his own family) has been corresponding with her, and sending registered mail--Which undoubtedly will mean her coming to this country--and being received by him--Last winter my husband $\mathrm{E}$ A T. went to Barbados and left us penniless--he stayed there 5 months--we had no 
support--from him--but the children and I depended on charity until we got a going--This woman is the outcome of his visit there. ${ }^{52}$

Similar letters reached consuls from islands and mainland alike. Most often, the relatives whose movements the authors sought to control were spouses, but there were others as well. Samuel D. of Atlantic City went to the trouble of notarizing the letter in which he informed the consul at Bridgetown that he had brought his seventeen-year-old daughter from Barbados to New Jersey (following the life cycle pattern so common before 1924) "but she refused to go to school and became very disobedient to me, her father. Her misbehaviour compelled me to send her back Home and she became incorrigible and her conduct to me was such that I felt she would not become a good American Citizen; and that she would be better off home with her mother. I further ask that she never be allowed to come to America again." ${ }^{\text {.5 }}$

Clyde Austin H. wrote to the same consul in the same year about his wife, who had left him four months earlier at her mother's urging. "Dear Consul, I would like to know, if it is possible for my wife to leave the Colony, without my knowledge or consent. As I am much grieved over the attitude. To my mind, I don't think your country is desirous of having women who desert their husbands through the indifferent actions of mothers." Revealing an apparently common conviction, which resembled none of the specifics of U.S. law and yet captured how its fixation on specific documents of identity was experienced on the island, Clyde wrote that he had always heard a wife could not go to the United States without the consent of her husband "and she must have one of his photos." If Clyde's wife had a photo of him now, he insisted, it was an old one acquired surreptitiously: "she haven't got it since she has left me.",54

As it happened, though, Clyde was out of luck. Although relatives' (or friends') support was, in 1923, a prerequisite for travel, relatives' opposition was not then enough to derail it. Lady Liberty was no more or less desirous of receiving "women who desert their husbands through the indifferent actions of mothers" than of receiving any other women from the islands. As the U.S. consul at Kingston explained to Robert B. (just back from Cuba in 1923 and convinced his wife, Eugenie, planned to depart Cuba for New York intending "never to return to her husband"), "lack of a husband's consent" was not "in itself sufficient to be a bar to entry." Unless the consul became convinced that Eugenie was ineligible for a visa--which in 1923 meant incapable of supporting herself, illiterate, or medically unfit--he "would not be inclined" to pass Robert's allegations along to authorities in New York. ${ }^{55}$

Attempts to use the power of papers and borders as leverage in intrafamily struggles were, then, nothing new. But even as the Johnson-Reed Act made it radically more difficult for British Caribbeans to facilitate the movement of kin across U.S. borders, it also offered more purchase to those seeking to block it. Again, the interrogation of Ada A. offers confirmation. By his own account, Samuel A. had sought assistance from multiple authorities in his struggles against his wife. When, after her departure, he heard rumors from friends back home that Ada had spent only four days in Barbados before heading on to Trinidad with Aubrey S., "I wrote to the Colonial Secretary at the Port of Spain, Trinidad and explained to him about her going off with this man with my money and he replied she was living at the home of the mother of this Aubrey S." One might well be amazed that Samuel got a reply at all, much less such an informative one. But at the end of the day, this attempt to pull the British colonial state into his conjugal conflict yielded no impact. Samuel also went to the British consul in New York to get a lawyer for a divorce, although he did not proceed with the process. Most effectively of all, two months after Ada's departure, Samuel lodged the affidavit alleging bad behavior and 
abandonment, which would successfully trigger a Special Inquiry when Ada attempted, in 1925, to disembark at Ellis Island.

Little wonder that Ada's description of her plight to her friend Edna James was not about eugenicist legislation or anti-immigrant nationalism but about Samuel's ability to marshal state power against her. Edna recalled, "I asked [Ada] what she was doing on Ellis Island and she told me she was being detained because her husband said she ran away from America and he was trying to stop her from coming to America." And he did. In the end, the board unanimously determined that Ada had failed to establish non-quota status--that she had not intended to return when she left in 1922. They also unanimously judged her "likely to become a public charge." That is, weighing on the one hand, the testimony of a husband who had remarried without divorcing her, had a child from a bigamous union on the way, had just quit his job for want of a raise, and when asked "Have you any savings?" responded, "I have $\$ 2$ in my pocket"--and on the other hand, a pledge of support from Ada's cousin Mae and a letter from Ada's sister's employer promising work in Philadelphia, the board had decided that this thirty-five-year-old woman, who had already made her way from Barbados to Panama to Barbados to Cuba to New York to Barbados to Trinidad to Barbados to New York, would find no way to support herself on northern soil.

April 1930 found Samuel A. in the heart of Barbadian Brooklyn with his wife Myrtle, whom he had married six years before. ${ }^{56}$ Like so many others of her generation, Myrtle had been raised by a grandmother in Barbados while her mother worked in Brooklyn; turning seventeen in 1923, she had left the island to join her mother in Gotham's working world. ${ }^{57}$ Myrtle arrived just before the imposition of Johnson-Reed's divide. Two years later--and two months before Myrtle and Samuel's daughter Adeline was born--Samuel A. successfully placed his first wife on the other side of the international barrier that U.S. immigration law had built.

British Caribbean families adapted to the radical new strictures imposed in 1924, as people do. Jamaicans and Barbadians and other islanders continued to enter the United States as best they could, through means that were legal or not. And individuals continued to try to use the powerful but unpredictable leverage offered by state interest in transnational family matters to their advantage. Let us glance forward one decade, and check on popular awareness of state interest in family ties. In 1937, Thomas D. wrote from Harlem to the U.S. Department of Labor to denounce his brother Ebenezer, who "had entered the U.S. illegally." Such a move might seem to suggest the weight of sibling loyalty was waning among British Caribbeans. But on the contrary, Thomas's letter attests to an enduring moral economy of family-of-origin ties that Ebenezer, putting conjugal needs first, had contravened. As a result of marrying a domineering New York wife, Ebenezer

neglected sending any help to his Father and Mother who are 83 and 70 years old respectively, he also has a boy child left there at home with the old folks and I have several letters in my possession from them telling me that sometimes for more than a year and other times once a year he would send a suit of clothing or two and not even a dollar to pay the duty on them. The burden of feeding [Ebenezer's child] is bourne by father out of what little assistance I send every month or what one of my other bros. at home is able to give him. ${ }^{58}$

How to make Ebenezer step up? Thomas first sought to use the specter of state power "just to scare [Ebenezer] to give some kind of aid better than he was doing since he had a steady job": Thomas "approached [Ebenezer] on the matter of neglecting his duty to his parents and his 
child through a selfish woman who he has no a single child with and threaten[ed] to take the matter up with authorities here." But the selfish woman called his bluff. Ebenezer's wife, Ione, had replied, in Thomas's words: "[I]f I [Thomas] even have him deported I [Ione] will see that he comes back here, so she has sent him out to get himself freed from fear any report I or anyone may make against him." That is, she sent Ebenezer down to Jamaica to petition for legal entry to the United States on the basis of their marriage. His first feint thus countered, Thomas sought to mobilize a higher authority. "So my reason for writing this letter and explaining," he concluded to the U.S. Secretary of Labor, "is to ask you to notify the U.S. Consulate in Kingston, Jam., BWI not to vise his pass port in a hurry for many years that he may realize his responsibilities there." $" 59$

Just as Thomas expected, Department of Labor officials sent a careful transcript of his letter to the consul at Kingston to inform deliberations in Ebenezer's case. One is struck both by the knowledge of U.S. immigration law built into this kitchen-table argument and by the particular points on which the confident and canny contenders at the table were wrong. Ione was right about which kin relations U.S. laws sanctioned and which they ignored, but not necessarily right that her marriage to Ebenezer would trump all as the wheels of state action ground forward. Meanwhile, Thomas was quite wrong about which kin ties would win support from U.S. immigration officials, but right that he could use his brother's vulnerability, as shaped by immigration restriction, to make Ebenezer's life difficult, and perhaps even push him out of ranks of residents and potential citizens entirely.

\section{Conclusion}

The rise of restrictionism in the interwar years is often figured as having been about bodies and blood, the physicality of human reproduction--and it was. But, for multiple reasons, it was also about hearts and minds, loyalty and desire. On the one hand, immigration incited concern precisely because of restrictionists' fears and fantasies about human desire: that sex across boundaries would dilute purities, that if one could not rely on "a feeling of caste or race reluctance as has served in the United States for a pronounced check upon white intermixture with black," the "extreme fecundity [of] the negro" would introduce indelible "black blood" into all other "stocks." Meanwhile, immigration restrictions were crafted in response to the initiatives migrants took in order to sustain family as they knew it - a dense web of obligation, labor, and love between brothers and sisters and cousins; daughters sweating in Manhattan to support the grandmothers raising those daughters' daughters back home.

That is, the emergent border control regime was shaped both by elite concern over dysgenic reproduction and by members of complicated families seeking advancement wherever they could find it, which, for sons and daughters from Naples to Nevis, by 1920 had routinely come to mean overseas. In attempting to ensure state control over population composition, the U.S. government put itself in the position of adjudicating family not only for its own citizens, not only for residents of its soil, but for the much larger universe of people seeking to become such. This meant not only policing bodies and acts but also assessing the dreams and desires that motivated them. That historical moment is nine decades gone, but the institutions it birthed guard our borders to this day. 


\section{NOTES}

1. Lucy Salyer, Laws Harsh as Tigers: Chinese Immigrants and the Shaping of Modern Immigration Law (Chapel Hill, NC, 1995); Erika Lee, At America's Gates: Chinese Immigration during the Exclusion Era, 1882-1943 (Chapel Hill, NC, 2003); Marilyn Lake and Henry Reynolds, Drawing the Global Colour Line: White Men's Countries and the International Challenge of Racial Equality (Cambridge, UK, 2008); Adam McKeown, Melancholy Order: Asian Migration and the Globalization of Borders (New York, 2008).

2. For example, Robert F. Foerster, The Racial Problems Involved in Immigration from Latin America and the West Indies to the United States: Hearings of the Committee on Immigration and Naturalization, House of Representatives, March 3, 1925 (Washington, DC, 1925); Charles B. Davenport and Morris Steggerda, Race Crossing in Jamaica (Washington, DC, 1929); Alexandra Minna Stern, Eugenic Nation: Faults and Frontiers of Better Breeding in Modern America (Berkeley, CA, 2005).

3. Eithne Luibheid, Entry Denied: Controlling Sexuality at the Border (Minneapolis, 2002); Martha Gardner, The Qualities of a Citizen: Women, Immigration, and Citizenship, 18701965 (Princeton, NJ, 2005); Deirdre M. Moloney, "Women, Sexual Morality, and Economic Dependency in Early U.S. Deportation Policy," Journal of Women's History 18, no. 2 (2006): 95-122; Lorna Biddle Rinear, "Phyllis Ann Edmeade (1920s): Caribbean Migrant Worker Deported from the United States," in The Human Tradition in the Black Atlantic, 1500-2000, ed. Beatriz G. Mamigonian, Karen Racine, Aaron P. Althouse, and Alan Bloom (Lanham, MD, 2010), 103-22; Nayan Shah, Stranger Intimacy: Contesting Race, Sexuality and the Law in the North American West (Berkeley, CA, 2011).

4. Catherine Lee, Fictive Kinship: Family Reunification and the Meaning of Race and Nation in American Immigration (New York, 2013). See also Nancy Cott, Public Vows: A History of Marriage and the Nation (Cambridge, MA, 2002), 133-55; Lara Putnam, "The Ties Allowed to Bind: Kinship Legalities and Migration Restriction in the Interwar Americas," International Labor and Working-Class History 83 (Spring 2013): 191-209. On contemporary experience, see Seyla Benhabib and Judith Resnick, eds., Migrations and Mobilities: Citizenship, Borders, and Gender (New York, 2009); and Deborah A. Boehm, Intimate Migrations: Gender, Family, and Illegality among Transnational Mexicans (New York, 2012).

5. Lara Putnam, "Unspoken Exclusions: Race, Nation, and Empire in the Immigration Restrictions of the 1920s in North America and the Greater Caribbean," in Workers across the Americas: The Transnational Turn in Labor History, ed. Leon Fink (New York, 2011), 267-94; Putnam, Radical Moves: Caribbean Migrants and the Politics of Race in the Jazz Age (Chapel Hill, NC, 2013), chap. 3.

6. Aristide Zolberg, "The Archaeology of "Remote Control,"” in Migration Control in the North Atlantic World: The Evolution of State Practices in Europe and the United States from the French Revolution to the Inter-War Period, ed. Andreas Fahrmeir, Olivier Faron, and Patrick Weil (New York, 2003), 195-222; Zolberg, A Nation by Design: Immigration Policy in the Fashioning of America (New York, 2006).

7. United States National Archive [henceforth, USNA], RG 84 Consular Posts, Havana, Cuba 523: Correspondence, American Consulate-General Habana Part XXI 1924, Classes 851-861.3: Cable from Department of State and reply from consul, Havana, December $15,1924$.

8. USNA, RG 84 Consular Posts, Bridgetown, Barbados, vol. 208 [henceforth, RG 84 vol. 208]: Correspondence, American Consulate, Barbados, 1925, vol. 3: Transcript, Board of 
Special Inquiry, Ellis Island, April 8, 1925: A-----, Ada. (Note: Surnames are omitted for private individuals tracked from confidential entry hearings.) In later testimony, Ada claimed to have lived in New York from 1917 to 1923, with only a brief detour to Havana to accompany her U.S. employer, but when she entered the United States in 1920 from Havana, she reported that it was her first entry to the country. Passenger List, S.S. Mexico, November 30, 1920, List 7. All passenger lists and census sheets cited in this essay have been accessed as digital images through Ancestry.com.

9. Cuba, Secretaría de Hacienda, Sección de Estadística, Informe y movimiento de pasajeros ... (Havana, 1917-1921).

10. Passenger List, S.S. Mascotte, August 24, 1920, List 164. U.S. Census 1920, Brooklyn Assembly District 1, Enumeration District 50, sheet 11B.

11. Passenger List, S.S. Mexico, November 30, 1920, List 7.

12. See U.S. Census of 1920, Brooklyn Assembly District 8, Enumeration District 435, Sheets 1A-XXB. (Sheet $17 \mathrm{~A}$ includes the home the couple would move into four months later.)

13. U.S. Census of 1920, New York, Brooklyn Assembly District 10, Enumeration District 588, Sheets 6A, 6B.

14. Elizabeth Mclean Petras, Jamaican Labor Migration: White Capital and Black Labor, 1850-1930 (Boulder, CO, 1988); Elizabeth M. Thomas-Hope, "The Establishment of a Migration Tradition: British West Indian Movements to the Hispanic Caribbean in the Century after Emancipation," in Caribbean Social Relations, ed. Colin G. Clarke (Liverpool, UK, 1978), 66-81; Putnam, Radical Moves, chap. 1.

15. Velma Newton, The Silver Men: West Indian Labour Migration to Panama, 18501914 (Mona, Jamaica, 1984); Bonham Richardson, Panama Money in Barbados, 1900-1920 (Knoxville, TN, 1985); Lara Putnam, The Company They Kept: Migrants and the Politics of Gender in Caribbean Costa Rica, 1870-1960 (Chapel Hill, NC, 2002); Jorge L. Giovannetti, "Black British Subjects in Cuba: Race, Ethnicity, Nation, and Identity in the Migratory Experience, 1898-1938" (PhD diss., University of North London, 2001); Cadence Wynter, "Jamaican Labor Migration to Cuba, 1885-1930, in the Caribbean Context" (PhD diss., University of Illinois at Chicago, 2001); Audrey K. Charlton, "Cat Born in Oven Is Not Bread': Jamaican and Barbadian Immigrants in Cuba between 1900 and 1959" (PhD diss., Columbia University, 2005).

16. See Irma Watkins-Owens, "Early Twentieth-Century Caribbean Women: Migration and Social Networks in New York City," in Islands in the City: Caribbean Migration to New York, ed. Nancy Foner (Berkeley, CA, 2001), 25-51. For region-wide sex ratio data, see Lara Putnam, "Rewriting Ravenstein from the Greater Caribbean," paper presented at the Social Science History Association 39th Annual Conference, Toronto, November 6-9, 2014.

17. Ira de Augustine Reid, The Negro Immigrant: His Background, Characteristics, and Social Adjustment, 1899-1937 (1939; New York, 1969), 243; Winston James, Holding Aloft the Banner of Ethiopia: Caribbean Radicalism in Early Twentieth-Century America (New York, 1998), 364.

18. Combining census data with annual entry data yields a estimated total of 89,600 black immigrants and their children in the city in 1925, who would have been at least forty-nine percent female, and the women among them overwhelmingly British West Indian. United States, Department of Commerce, Bureau of the Census, Fifteenth Census of the United States: 1930, Vol. 2 (Washington, DC, 1933), 70, 446; Trinidad, Registrar General, Census of the Colony of 
Trinidad and Tobago, 1921 (Port of Spain, 1923), 59; George W. Roberts, The Population of Jamaica (Cambridge, UK, 1957), 51, 72.

19. United States, Fifteenth Census of the United States, Vol. 2, 33, 70, 231, 250. Census figures for foreign-born "West Indians" in New York include Cubans, French Caribbeans, and others (although not Puerto Ricans or U.S. Virgin Islanders). Combining the available census evidence on race, birthplace, and nationality suggests a total of 55,000 British Caribbean-born and 45,000 of their children citywide in 1930. Key scholarship on British Caribbeans in the early twentieth-century United States includes Irma Watkins-Owens, Blood Relations: Caribbean Immigrants and the Harlem Community, 1900-1930 (Bloomington, IN, 1996); James, Holding Aloft the Banner; Joyce Moore Turner with W. Burghardt Turner, Caribbean Crusaders and the Harlem Renaissance (Urbana, IL, 2005); Louis J. Parascandola, ed., Look for Me All around You: Anglophone Caribbean Immigrants in the Harlem Renaissance (Detroit, 2005); Violet Showers Johnson, The Other Black Bostonians: West Indians in Boston, 1900-1950 (Bloomington, IN, 2006). See also Ira Kasinitz, Caribbean New York: Black Immigrants and the Politics of Race (Ithaca, NY, 1992); and Nancy Foner, In a New Land: A Comparative View of Immigration (New York, 2005), both focused on a later era but offering key insights into the earlier wave.

20. Roi Ottley, New World A'Coming (Boston, 1943), 40-41. Ottley's book offers a vivid portrait of British Caribbean New York, as do Claude McKay's Negro Metropolis (New York, 1940); and Ira de Augustine Reid's Negro Immigrant. McKay was a Jamaican immigrant (arrived 1912); Reid was the U.S.-born son of Jamaican minister (arrived 1892). Equally essential are works by the daughters of 1920s arrivals, including Paule Marshall, Brown Girl, Brownstones (1959; New York, 1981); Marshall, Triangular Road: A Memoir (New York, 2009); Audre Lorde, Zami: A New Spelling of My Name (Freedom, CA, 1982); June Jordan, Soldier: A Poet's Childhood (New York, 2001); and Yevette Richards, ed., Conversations with Maida Springer: A Personal History of Labor, Race, and International Relations (Pittsburgh, PA, 2004).

21. U.S. Census of 1920, Borough of Manhattan, Enumeration District 1414, Sheet No. 1855.

22. Passenger list for S.S. Advance, sailing from Cristobal, June 10, 1918; passenger list for S.S. Almirante, sailing from Kingston, May 6, 1916.

23. U.S. Census of 1930, Borough of Manhattan, Enumeration District 31-1003, Sheet No. 8B.

24. Ibid.

25. But see Watkins-Owens, Blood Relations; Watkins-Owens, "Early TwentiethCentury Caribbean Women"; Putnam, "Ties Allowed to Bind." Gender and kinship have been prominent in research on post-World War II migration, including Constance Sutton and Elsa M. Chaney, eds., Caribbean Life in New York City: Sociocultural Dimensions (1987; New York, 1992); Mary Chamberlain, Family Love in the Diaspora: Migration and the Anglo-Caribbean Experience (New Brunswick, NJ, 2006); and Karen Fog Olwig, Caribbean Journeys: An Ethnography of Migration and Home in Three Family Networks (Durham, NC, 2007).

26. Reid, Negro Immigrant, 243.

27. Pioneering studies were Fernando Henriques, Family and Colour in Jamaica (London, 1953); Raymond T. Smith, The Negro Family in British Guiana: Family Structure and Social Status in the Villages (London, 1956); Roberts, Population of Jamaica; Edith Clarke, My Mother Who Fathered Me: A Study of the Families in Three Selected Communities in Jamaica 
(London, 1957); Michael G. Smith, West Indian Family Structure (Seattle, WA, 1962). Not just the literature on Caribbean kinship, but the literature on that literature is quite large. See Raymond T. Smith, "Family, Social Change, and Social Policy in the West Indies," Nieuwe West-Indische Gids: New West Indies Guide 56, nos. 3-4 (1982): 111-42, Christine Barrow, Family in the Caribbean: Themes and Perspectives (Kingston, 1996); Mary Chamberlain, "Small Worlds: Childhood and Empire," Journal of Family History 27, no. 2 (2002): 186-200; D. Alissa Trotz, "Behind the Banner of Culture: Gender, 'Race,' and the Family in Guyana," Nieuwe West-Indische Gids: New West Indies Guide 77, nos. 1-2 (2003): 5-29; Lara Putnam, "Caribbean Kinship from Within and Without," History Workshop Journal 66, no. 1 (2008): 279-88; Barbara Bush, "Colonial Research and the Social Sciences at the End of Empire: The West Indian Social Survey, 1944-57," Journal of Imperial and Commonwealth History 41, no. 3 (2013): 451-74. Crucial recent contributions on nineteenth- and early twentieth-century family practice include Jean Besson, Martha Brae's Two Histories: European Expansion and Caribbean CultureBuilding in Jamaica (Chapel Hill, NC, 2002); Brian L. Moore and Michele A. Johnson, Neither Led nor Driven: Contesting British Cultural Imperialism in Jamaica, 1865-1920 (Mona, Jamaica, 2004); Henrice Altink, Destined for a Life of Service: Defining African-Jamaican Womanhood, 1865-1938 (Manchester, UK, 2011).

28. Given the unevenness of information on kin forms before the nineteenth-century emergence of intense labor mobility, it is hard to establish chronology, much less causation.

29. USNA, RG 84 Consular Posts, Kingston, Jamaica, vol. 329 [henceforth, RG 84 vol. 329]: Correspondence, American Consulate, Kingston JA 1924 Part 8: Letter from U.S. consul, Kingston, to U.S. consulate, London, September 6, 1924. On child fostering, see also Watkins-Owens, "Early Twentieth-Century Caribbean Women," 39-42.

30. USNA, RG 84 Consular Posts, Kingston, Jamaica, vol. 321 [henceforth, RG 84 vol. 321]: Correspondence, American Consulate, Kingston JA 1923 Part 5: Letter to consul, February 13, 1923.

31. Note that all of the sons were in factory work, and Brown himself appears in 1925 as an elevator operator--underlining the narrowness of class hierarchies among British West Indian migrants. New York State Population Census Schedules, 1925; Election District: 27; Assembly District: 13; City: New York; County: New York; Page: 12.

32. RG 84 vol. 321: Correspondence, American Consulate, Kingston JA 1923 Part 5: Letter to consul, Jan. 1923. Parents of U.S. citizens were exempted from the literacy requirements instituted by the Immigration Act of 1917.

33. RG 84 vol. 208: Correspondence, American Consulate, Barbados, 1925, vol. 3:

Transcript, Board of Special Inquiry, Ellis Island, October 8, 1924: B-------, Donald.

34. See Mae Ngai, Impossible Subjects: Illegal Immigrants and the Making of Modern America (Princeton, NJ, 2004); Putnam, Radical Moves, chap. 3.

35. RG 84 vol. 321: Correspondence, American Consulate, Kingston JA 1923 Part 5: Letter to consul, March 22, 1923; letters from consul, January 16, 1923 and April 6, 1923.

36. For extended discussion, see Putnam, "Ties Allowed to Bind."

37. Reid, Negro Immigrant, 249. Wives and minor children of U.S. permanent residents were given second-rank priority (secondary to parents of U.S. citizens) for one-half of allocated quota visa numbers each year. But, in practice, with only a few hundred quota visas available annually for the entire British Caribbean, and waiting lists ten times longer than the annual supply at each of the region's consulates, this "preferred status" meant almost nothing. 
38. RG 84 vol. 208: Correspondence, American Consulate, Barbados, 1925, vol. 3 : Letter to consul, April 7, 1925.

39. RG 84 vol. 208: Correspondence, American Consulate, Barbados, 1925, vol. 3: Letter to consul, May 29, 1925.

40. RG 84 vol. 208: Correspondence, American Consulate, Barbados, 1925, vol. 3: Letter to consul, March 27, 1925; Letter from consul, April 14, 1925.

41. RG 84 vol. 329: Correspondence, American Consulate, Kingston JA 1924 Part 8: letter from consul, Kingston, to U.S. consulate, London, September 6, 1924.

42. For example, among many, USNA, RG 84 Consular Post Kingston, Jamaica, vol. 352: Consular Post Kingston, Jamaica, 1926, Correspondence 811.11: Letter from consul, November 16, 1926.

43. United States, Department of State, Admission of Aliens into the United States: Notes to Section 361, Consular Regulations (Washington, DC, 1932), 79.

44. Ibid., 89.

45. RG 84 vol. 208: Correspondence, American Consulate, Barbados, 1925, vol. 3:

Transcript, Board of Special Inquiry, Ellis Island, April 8, 1925: A----, Ada. All information and quotes unattributed in the paragraphs that follow come from this eleven-page transcript.

46. Passenger List, S.S. Voltaire, April 4, 1925, List 31.

47. United States, Department of State, Admission of Aliens, 89.

48. U.S. Census of 1930, New York, Borough of Brooklyn, Assembly District 10, Enumeration District 24-1486, Sheet 6B.

49. United States, Department of State, Admission of Aliens, 89.

50. RG 84 vol. 208: Correspondence, American Consulate, Barbados, 1925, vol. 3: Letter to consul, March 17, 1925; cf. letter to consul, August 15, 1925.

51. See Putnam, Company They Kept.

52. USNA, RG 84 Consular Posts, Bridgetown, Barbados, vol. 201 [henceforth, RG 84 vol. 201]: Correspondence, American Consulate, Barbados, 1923, vol. 2: Letter to consul, July 281923.

53. RG 84 vol. 201: Correspondence, American Consulate, Barbados, 1923, vol. 2: Letter to consul, June 5, 1923.

54. RG 84 vol. 201: Correspondence, American Consulate, Barbados, 1923, vol. 2: Letter to consul, November 20, 1923.

55. RG 84 vol. 321: Correspondence, American Consulate, Kingston JA 1923 Part 5: Letter to consul, May 7, 1923; letter from consul, May 9, 1923.

56. U.S. Census of 1930, New York, Borough of Brooklyn, Assembly District 10, Enumeration District 24-1486, Sheet 6B.

57. Passenger List, S.S. Hubert, July 16, 1923, List 2.

58. USNA, RG 84 Jamaica, Kingston Consulate, Consul Records, 1936-1952, Entry 2821, Box 2: c8.1 496 (1937, vol. 9. Classes 6-8): Letter to consul, May 18, 1937.

59. Ibid.

60. Foerster, Racial Problems, 321; Lothrop Stoddard, The Rising Tide of Color against White World Supremacy (New York, 1920), 90; Carleton Beals, "The Black Belt of the Caribbean," Fortnightly Review, September 1, 1931: 357-59, 366-67. 